\title{
Imbedding HACCP principles in dairy herd health and production management: Case report on calf rearing
}

\author{
Boersema, J.S.C. ${ }^{1}$, Noordhuizen, J.P.T.M. ${ }^{2,3}$, Vieira, A. ${ }^{4}$, Lievaart, J.J. ${ }^{5}$ and Baumgartner, W. ${ }^{6}$ \\ ${ }^{1}$ University of Utrecht, Department of Farm Animal Health, Faculty of Veterinary Medicine Utrecht, Netherlands \\ 2 University of Gent, Faculty of Veterinary Medicine, Belgium \\ ${ }^{3}$ Ecole Nationale Vétérinaire de Lyon, Département Elevage, Santé et Qualité des Productions, Marcy-l’Etoile, \\ France \\ ${ }^{4}$ Vacqa-International, Santarém, Portugal \\ ${ }^{5}$ Charles Sturt University, School of Veterinary and Animal Science,Wagga Wagga, Australia \\ ${ }^{6}$ University of Veterinary Medicine Vienna, Clinic for Ruminants, Department for Farm Animals and Herd Management, \\ Austria
}

\begin{abstract}
Driven by consumer demands, European legislation has suggested the use of HACCP (Hazard Analysis Critical Control Point) as the quality risk management programme for the whole dairy chain. Until now, an exception has been made for primary producers, but as regulations evolve, on-farm HACCP-like programmes should be ready to assure food safety as well as animal health and animal welfare. In our field experiment, the HACCP-concept was used to combine both optimal farm management and formalisation of quality assurance in an on-farm situation in the Netherlands. The process of young stock rearing was chosen, since its importance for the future of the farm is often underestimated. Hazards and their associated risk factors can be controlled within the farm-specific standards and tolerances, as targets can be controlled by corrective measures and by implementation of farm-specific worksheets. The veterinarian is pivotal for the facility-based HACCP team, since he/she has knowledge about on-farm risk assessment and relations between clinical pathology, feed and farm management. The HACCP concept in combination with veterinary herd health and production management programmes offers a promising approach to optimise on-farm production processes (i.e., young stock rearing) in addition to a structural approach for quality risk management on dairy farms.
\end{abstract}

Keywords: calf rearing, HACCP-like programme, herd health and production management, quality risk management

Corresponding author:

J.S.C. Boersema

Staationsstraat 2, 9988RP

Usquert The Netherlands

Email: j.s.c.boersema@uu.nl

Phone: +31628087110

Irish Veterinary Journal Volume 61 Number 9 594-602, 2008

\section{Introduction}

According to European legislation, the hazard analysis critical control point (HACCP) concept has been applied in the food chain since 1998 and has been incorporated in the new food hygiene package since January 2006. An exception was made for producers of primary products (e.g., dairy farmers). However, primary production should be performed according to the principles of food safety and hygiene codes following European Union (EU) directives 852/853/854-2004. Within a few years, implementation of the HACCP concept may also become compulsory for dairy farms, since this has already been suggested in EU regulation 178-2002, the General Food Law (Maunsell and Bolton, 2004). In response to these European regulations, Friesland Dairy Foods FDF (a Dutch dairy processing co-operative) recently introduced 'Qarant'. This quality assurance programme starting at dairy farm level deals with food safety, animal health and animal welfare issues to take account of the demands of consumers and retailers.
During daily work, or in the framework of herd health $(\mathrm{HH})$ and production management programmes (PM) both farmers and veterinarians are dealing with risk assessment. In order to optimise on-farm processes, they attempt to control on-farm processes (Brand et al., 1996). The HACCP concept appears to be very promising for application on farms because it is farm-specific, relatively low in labour and record-keeping demands, focused on risk management and prevention, easy to link to both operational management and food chain quality assurance and suitable for certification (Noordhuizen, 2004; Noordhuizen and Metz, 2005). In fact, introduction of HACCP on dairy farms means nothing more than "structuring and formalising what the truly good farmer would be doing anyway" (Ryan et al., 1997).

The rearing of young stock is one of the main processes on farms; it represents a large cost within dairy farming, however often too little attention is paid to this process (Roy et al, 1984; Brand et al., 1996; Quigley III et al., 1996; Mourits et al., 1997; Garnsworthy et al., 2005). This inevitably leads 
to (often undetected) losses, particularly because over the last few years dairy farming has become less profitable in the Netherlands due to declining milk and meat prices and high resource costs (LEI 2005).

Until now, the introduction of HACCP principles in on-farm management have hardly been tested in practice

(Noordhuizen, 2004), due to many objectively immeasurable processes in an on-farm situation, a HACCP like approach should be applied (Heeschen and Blüthgen, 2003). In accordance with increasing quality risk control demands of food processing industries for primary producer and, in order to prevent top-down impractical measures in response to European food safety regulations, we used this field experiment to test the practical applicability of the HACCP concept. We aimed at optimising young stock rearing and formalisation of quality assurance in an on-farm situation by using a HACCP-like approach in combination with existing $\mathrm{HH}$ and PM programmes.

\section{Materials and methods \\ HACCP steps}

The 12 steps for on-farm development and implementation of HACCP programme, presented by Cullor (1995) were adjusted to the young stock rearing process. The modified steps are shown in Table 1.

Table 1: The adjusted 12 steps to implement HACCP (adapted after Cullor, 1995).

Assemble a multidisciplinary, facility-based HACCP team, including farmer, calf stockperson, veterinarian and HACCP manager;

2 Set on-farm targets in young stock rearing;

3 Identify the intended use of the 'product' (and the targeted purchaser);

$4 \quad$ Develop a flow diagram that describes the young stock rearing process, and a map indicating how and where the young stock is housed and/or pastured;

5 Verify the flow-diagram and housing map on-site;

6 Principle 1: Prepare a list of steps in the production process at which targeted hazards occur;

$7 \quad$ Principle 2: Identify the critical control points (CCP) and points of particular attention (POPA) in the production process required to reduce or eliminate the hazards/risks;

8 Principle 3: Establish standards and tolerances, or targets for triggering the implementation of corrective and preventive measures associated with each critical control point or point of particular attention identified;

9 Principle 4: Establish monitoring requirements for CCPs and POPAs, in order to adjust procedures and maintain control of the production process, e.g., monthly data inspection; visual inspection of hygiene in neonate calf house;

10 Principle 5: Determine corrective measures to take when monitoring indicates that a value falls outside established norms, on-farm tolerances or targets;

11 Principle 6: Establish effective record-keeping procedures which document that the HACCP programme has been implemented; and,

12 Principle 7: Establish procedures to verify the HACCP programme is working correctly (e.g., internal and external verification by young stock/ dairy experts and yearly revision of all work sheets, operation management sheets and biosecurity plans).

\section{Structure of field experiment}

A veterinary practice in the northern part of the Netherlands was approached to participate in the project. This practice includes over 80 dairy farmers, offers work to three ruminant specialists and has implemented dairy $\mathrm{HH}$ and PM programmes for many years. Two dairy farmers (farm $\mathrm{H}$ and farm $\mathrm{M}$ ) were willing to spend extra time for this field experiment. Visits to both farms were planned together with the veterinarians' visits in the framework of the $\mathrm{HH}$ and PM programme, in which both farms take part. Both farms rear their own young stock.

The structure and purpose of every visit is illustrated in Table 2. The HACCP team consisted of the farmer, (worker), veterinarian and HACCP manager. In the framework of the $\mathrm{HH}$ and PM programme, farmers and veterinarian already had good record-keeping procedures. Farm incidences, referring to incidence of diseases or disorders, from the 12-month lists and online farm data (PIR-DAP) were used for implementation of the HACCP programme. Specific HACCP record-keeping procedures, Step 11, were partly developed during the field experiment (see results).

Table 2: Structure and purpose of farm visits (for specification of HACCP steps see Table 1)

\begin{tabular}{|c|c|c|c|}
\hline $\begin{array}{l}\text { Farm visit } \\
\text { (month) }\end{array}$ & $\begin{array}{l}\text { Discussion } \\
\text { inside 'at the } \\
\text { kitchen table' \& } \\
\text { purpose }\end{array}$ & $\begin{array}{l}\text { Practical issues } \\
\text { outside in the } \\
\text { barn' }\end{array}$ & HACCP steps \\
\hline February & $\begin{array}{l}\text { Explain } \\
\text { purpose of field } \\
\text { experiment. } \\
\text { General } \\
\text { discussion } \\
\text { to get insight } \\
\text { in on-farm } \\
\text { young stock } \\
\text { management. } \\
\text { Creating } \\
\text { the process } \\
\text { diagram. }\end{array}$ & $\begin{array}{l}\text { Tour and } \\
\text { inspection of } \\
\text { the farm, to } \\
\text { get a general } \\
\text { impression } \\
\text { and verification } \\
\text { of the young } \\
\text { stock rearing } \\
\text { management. }\end{array}$ & $\begin{array}{l}\text { Step two and } \\
\text { three. } \\
\text { Step four. }\end{array}$ \\
\hline March & $\begin{array}{l}\text { Verify the } \\
\text { process } \\
\text { diagram. } \\
\text { Identify the } \\
\text { hazards and } \\
\text { CCP's. } \\
\text { Set targets and } \\
\text { tolerances. } \\
\text { Discuss plan } \\
\text { of action / } \\
\text { protocols } \\
\text { (e.g. parts } \\
\text { from HACCP } \\
\text { Handbook for } \\
\text { young stock } \\
\text { rearing). }\end{array}$ & $\begin{array}{l}\text { Determine IgG } \\
\text { level in calves. } \\
\text { Young stock } \\
\text { growth } \\
\text { measurements. }\end{array}$ & $\begin{array}{l}\text { Step five. } \\
\text { Step six and } \\
\text { seven. } \\
\text { Step eight. } \\
\text { Step nine and } \\
\text { ten. } \\
\text { Step eleven. }\end{array}$ \\
\hline May & $\begin{array}{l}\text { Evaluation of } \\
\text { the HACCP field } \\
\text { experiment. }\end{array}$ & $\begin{array}{l}\text { Tour and } \\
\text { inspection of } \\
\text { the farm, to } \\
\text { get a general } \\
\text { impression } \\
\text { and verification } \\
\text { of the young } \\
\text { stock rearing } \\
\text { management. } \\
\text { Determine IgG } \\
\text { level in calves. }\end{array}$ & $\begin{array}{l}\text { Step twelve. } \\
\text { Step nine. }\end{array}$ \\
\hline
\end{tabular}




\section{Farm visits and data collection}

In order to identify the hazards and critical control points (CCP) and to set the targets and tolerances, sufficient information and data were collected during the first farm visit (interview, tour and inspection on farm and data from farm records). In order to get an insight of the farmers' opinion about the main hazards in young stock management, farmers were asked to fill in a form concerning strong and weak points in the farm management. After this form was sent back by the farmer, together with prevalence data from the farm records, the remaining steps five, six, seven and eight were completed by the HACCP team before the second visit took take place.

Young stock management was divided into periods, conforming to age groups, consisting only of female animals, which are moved to another pen once every few months. Furthermore, management consists of the following five components: housing, feed (colostrum, milk and rations), insemination, care and responsibilities. The total management was recorded in assessing strengths and weaknesses ( $\mathrm{S}$ and $\mathrm{W}$ ), with items on general management practices, strong points and points of particular attention (hazards and risks). Part of this farm-specific $\mathrm{S}$ and $\mathrm{W}$ format is shown in Table 3.

Since the main hazards on the farms were strongly related to the risk 'poor colostrum management', blood from four to five calves (aged two to five days) was taken a week before the second visit. From the serum, total protein and IgG levels were determined in order to evaluate colostrum management (Dewell et al., 2006). During the second farm visit, all young stock from calf up to pregnant heifers, prior to calving were weighed and body condition was scored (Brand et al., 1996). The bodyweight of animals was estimated using heart girth measurements carried out by one person with a weighing-tape (ANImeter, Instruvet, Croatia). Since clear relations between heart girth and body weight have been demonstrated by Heinrichs $e t$ al. (1992), heart girth measurement is a validated way of determining weight (and growth) in young dairy stock. Thereafter, trend lines for on-farm growth performance could be calculated, and tolerances for minimum (and maximum) weight could be determined using Microsoft Office Excel.

The needs, contents and functionality of work instructions developed for operational management protocols were also discussed during visit two. The targets, which were set before visit two, were evaluated during the final visit. A week before the final visit, blood samples were taken from four calves on farm $\mathrm{H}$, enabling another evaluation of the colostrum management. Finally, farmers were asked to fill in an evaluation form.

Results from each farm visit were recorded and feedback was given to the farmers and their veterinarian by email and telephone, so that all joint parties were in agreement before the next visit would take place.

\section{Results \\ HACCP procedure}

Steps two and three

In steps two and three, the team should identify the targets for young stock rearing. The general target on both farms was similar; heifers should calve at, or before 24 months of age. This means that heifers should be pregnant at 15 months or earlier, which implies that insemination is started at an age of 13 months, at a preferable weight of $370 \mathrm{~kg}$.

\section{Steps four and five}

Figure 1 an example of a process diagram is shown. In this diagram, subsequent steps in the rearing period, together with the related management actions and the person responsible for those actions are shown. An overview of the young stock housing was also drawn in order to support team discussions.

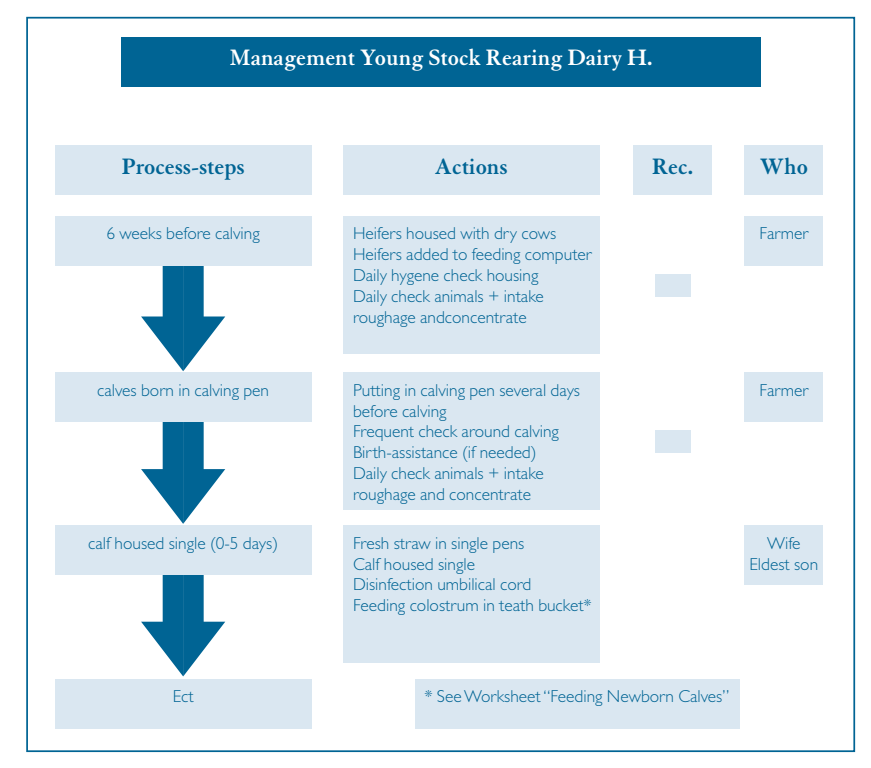

Figure 1: Process-diagram young stock rearing farm $\mathrm{H}$

Steps six and seven

The young stock management itself was assessed by an interview with the farmer and an inspection tour of the farm. This management overview is shown in Table 2 . No conclusions can be drawn from the management overview shown in Table 2. Points of particular attention (POPAs) are conditions that could be threatening to animal health, animal welfare, public health or on-farm management. To establish whether POPAs are critical, focus is placed on management in relation to herd data or results on a yearly basis. Farms $\mathrm{H}$ and $\mathrm{M}$ already took part in a $\mathrm{HH}$ and PM programme and recorded general herd data, disease and disorder prevalences in so called 12-month lists of herd performance parameters. Relevant data for evaluating young stock management were taken from the 12-month lists and are shown in Table 4 and Table 5.

The final result of step 6 is the identification of the main hazards which occur in young stock management. No more than three or four hazards were selected for control in the field experiment, because otherwise the programme would 
Table 3: Example of a management overview in SWOT format

\begin{tabular}{|c|c|c|}
\hline General management practices & Strong points & Points of particular attention (risks) \\
\hline \multicolumn{3}{|l|}{ Period till calving } \\
\hline $\begin{array}{l}\text { Ration: } \\
\text { Comparable to ration dairy cows (mixture } \\
\text { of roughage A, corn, brewers grain and } \\
\text { minerals). } \\
\text { Transition concentrate UTD (dry period six } \\
\text { weeks). } \\
\text { From } 21 \text { days dry: } 0,5 \mathrm{~kg} / \text { day. } \\
\text { Increase (in } 21 \text { days) to } 4 \mathrm{~kg} / \text { day prior to } \\
\text { calving. }\end{array}$ & Fresh feed is provided daily. & $\begin{array}{l}\text { Dry cows are fed an energy-rich ration } \\
\text { throughout the whole dry period (>risk for } \\
\text { overconditioning). }\end{array}$ \\
\hline $\begin{array}{l}\text { Housing: Free stall barn + cubicles } \\
\text { (concrete + saw dust). }\end{array}$ & $\begin{array}{l}\text { Heifers together with dry cows; separated } \\
\text { from the rest of the herd. } \\
\text { Enough feeding places and space to lie } \\
\text { down for all dry cows and heifers. }\end{array}$ & $\begin{array}{l}\text { Animals are a bit restless (rank fights, } \\
\text { some pregnant heifers were just added to } \\
\text { the dry cows group). }\end{array}$ \\
\hline Calving: Two times a day fresh feed. & $\begin{array}{l}\text { Cows/heifers calf in a maternity pen. } \\
\text { Fresh straw. } \\
\text { Feed intake is watched. }\end{array}$ & $\begin{array}{l}\text { Couple of days in maternity pen } \\
\text { Dung is not removed before the next cow/ } \\
\text { heifer enters the maternity pen. } \\
\text { III cows are housed in the same pen. } \\
\text {-Supervision is mostly lacking, if a cow/ } \\
\text { heifer calves at night (>risk of stillbirth and } \\
\text { less optimal colostrum-intake calf). }\end{array}$ \\
\hline Heifers in the herd after calving. & $\begin{array}{l}\text { Heifers do very well in the herd. } \\
\text { Milk yield level is higher than in cows. }\end{array}$ & \\
\hline \multicolumn{3}{|l|}{ Day I-5 after birth } \\
\hline $\begin{array}{l}\text { Feeding colostrum (Three days in } \\
\text { total). } \\
\text { Teatbucket feeding: } \\
\text { 1st time: } 1-2 \text { litres (depending on how } \\
\text { willingly a calf drinks) } \\
\text { From } 2 \text { nd time: } 2 \text { litres two times/day. }\end{array}$ & $\begin{array}{l}\text { Teat buckets are always clean before } \\
\text { feeding and cleaned/dried afterwards. }\end{array}$ & $\begin{array}{l}\text { Umbilical cord is not disinfected (>risk for } \\
\text { inflammation). } \\
\text { Calves frequently do not get their first } \\
\text { colostrum within four hours after birth } \\
\text { (especially when they are born at night) } \\
\text { (risk for Failure of First Passage). }\end{array}$ \\
\hline $\begin{array}{l}\text { Feeding milk-replacer. } \\
\text { Switched to milk replacer at once (on day } \\
\text { four). } \\
2 \text { litres } 2 \text { times/day (teatbucket). } \\
\text { From day five with automatic milk feeder. }\end{array}$ & & \\
\hline
\end{tabular}

Table 4: Data from 12-month list of farm $\mathrm{M}$ in the $\mathrm{HH}$ and PM programme, $\%$ in months February until May were converted to prevalence figures on a yearly basis

\begin{tabular}{|c|c|c|c|c|c|c|c|}
\hline \multirow[t]{2}{*}{ Disease/ Disorder } & \multicolumn{7}{|c|}{$\begin{array}{c}\text { M } \\
\text { (100 dairy cows, yearly } 40 \% \text { fresh heifers) }\end{array}$} \\
\hline & $\begin{array}{l}\# \text { on } * \\
08 / 02\end{array}$ & $\begin{array}{l}\text { \# on } \\
09 / 03\end{array}$ & $\begin{array}{l}\text { \# on } \\
06 / 04\end{array}$ & $\begin{array}{l}\text { \# on } \\
04 / 05\end{array}$ & $\begin{array}{l}\text { Year'05- } \\
\text { '06 }\end{array}$ & Target & $\begin{array}{l}\text { February } \\
\text {-May } \\
(\mathrm{Yb})\end{array}$ \\
\hline \# abortion & 0 & 0 & 0 & 0 & $2 \%$ & $\leq 2 \%$ & $0 \%$ \\
\hline \# abnormal births & 0 & 0 & 1 & 0 & $3 \%$ & $0 \%$ & $3 \%$ \\
\hline \# calves dead at birth & 1 & 0 & 1 & 0 & $6 \%$ & $\leq 5 \%$ & $7 \%$ \\
\hline \# calves dead $>24 \mathrm{hr}$ & 0 & 0 & 1 & 0 & $5 \%$ & $\leq 3 \%$ & $3 \%$ \\
\hline \# calves: diarrhoea & 0 & 0 & 0 & 0 & $0 \%$ & $\leq 2 \%$ & $0 \%$ \\
\hline \# calves: cough & 2 & 2 & 2 & 1 & $29 \%$ & $\leq 5 \%$ & $17 \%$ \\
\hline \# barren heifers & 0 & 0 & 1 & 0 & $19 \%$ & $\leq 30 \%$ & $5 \%$ \\
\hline $\begin{array}{l}\text { \# inseminations/ } \\
\text { heifer }\end{array}$ & - & - & - & - & 2.04 & 2.00 & 2.19 \\
\hline
\end{tabular}

Step eight

Targets and tolerances that were set in the HACCP on-farm programmes, in order to control specific diseases or disorders on farms $\mathrm{H}$ and $\mathrm{M}$, can be found in Table 4 and Table 5. Many of them were already set in the framework of $\mathrm{HH}$ and $\mathrm{PM}$, but could be modified (e.g., set lower than they were) and supported by data for economic losses

* $=$ number of disease cases in the month prior to the farm visit.

become too complex and overview would be quickly lost. In Table 6 an example of a HACCP table is presented, showing which hazards could be selected from the young stock rearing process. In the second column the main risk factors, which are most probably contributing to the occurrence of the related hazards on the particular farm, are listed. In order to fulfil Step seven of the HACCP concept, CCPs or POPAs have to be identified. CCPs meet a set of formal criteria; POPAs fail to meet one or more of these criteria. (see also Lievaart et al., 2005).

\section{Step nine}

Requirements for monitoring the mentioned hazards or risks are shown in Table 6. Monitoring should be regular and frequent enough to timely reveal deviations in the system, but should also be reliable, practical and not too time consuming.

\section{Farm specific monitoring results}

As a rule, the 12-month list will have been discussed at the monthly visit in the framework of $\mathrm{HH}$ and PM. Results 
Table 5: Serum immunoglobulin G (IgG; g/l) and total protein (TP; $\mathrm{g} / \mathrm{l})$ levels in calves aging two to five days

\begin{tabular}{|c|c|c|c|c|c|c|c|c|c|c|c|}
\hline Dairy Farm & \multicolumn{4}{|c|}{$\mathrm{H}$} & \multicolumn{4}{|c|}{ M } & \multicolumn{3}{|c|}{ Reference value (g/l) } \\
\hline Date & \multicolumn{2}{|c|}{ 22/02 } & \multicolumn{2}{|c|}{$03 / 05 *$} & \multicolumn{2}{|c|}{$22 / 02$} & \multicolumn{2}{|c|}{$-* *$} & \multicolumn{2}{|c|}{ IgG } & TP \\
\hline $\begin{array}{l}\text { Sample } \\
* * *\end{array}$ & IgG & TP & IgG & TP & $\lg G$ & TP & $\lg G$ & TP & 5 & Very poor & \multirow{6}{*}{$\begin{array}{l}60 \pm 7 \\
\text { (at } 48 \mathrm{~h} \\
\text { after birth) }\end{array}$} \\
\hline 1 & 6 & 49 & 12 & 58 & 19 & 72 & - & - & & & \\
\hline 2 & 10 & 63 & 11 & 58 & 13 & 63 & - & - & $5-10$ & Insufficient & \\
\hline 3 & 5 & 49 & 11 & 60 & 21 & 76 & - & - & $10-15$ & Sufficient & \\
\hline 4 & 9 & 59 & 14 & 58 & 9 & 61 & - & - & $>15$ & Good & \\
\hline 5 & - & - & 14 & 59 & - & - & - & - & & & \\
\hline
\end{tabular}

* = levels for both IgG and TP are significantly higher at the second test.

** = the levels for IgG and TP in the first test gave no need for a second check.

*** $=$ for IgG monitoring, 3-5 samples are recommended by the Dutch Animal Health Service.

Table 6: Monitoring requirements and worksheets

\begin{tabular}{|c|c|c|c|c|c|}
\hline Hazards & $\begin{array}{l}\text { Main risk } \\
\text { factor }\end{array}$ & $\begin{array}{l}-\mathrm{CCP} \\
-\mathrm{POPA}\end{array}$ & Monitoring & Work sheets & $\begin{array}{l}\text { Targets } \\
\text { (yearly } \\
\text { basis) }\end{array}$ \\
\hline $\begin{array}{l}\text {-Diarrhoea (in } \\
\text { neonate or older } \\
\text { calf). } \\
\text {-Respiratory } \\
\text { disorder. }\end{array}$ & $\begin{array}{l}\text { Insufficient } \\
\text { colostrum } \\
\text { intake. }\end{array}$ & $\begin{array}{l}\text {-Measure } \\
\text { prevalence. } \\
\text {-IgG level } \\
\text { serum in } \\
\text { calves aged } \\
\text { 2-5 days. }\end{array}$ & $\begin{array}{l}\text {-Monthly dairy } \\
\text { data evaluation. } \\
\text {-Monthly lgG } \\
\text { level serum } \\
\text { check } \\
\text { or } \\
\text { lgG level } \\
\text { colostrum } \\
\text { check (each } \\
\text { calf). }\end{array}$ & $\begin{array}{l}\text { "Feeding } \\
\text { newborn } \\
\text { calves." }\end{array}$ & $\begin{array}{l}\leq 3 \% \\
\leq 3 \%\end{array}$ \\
\hline $\begin{array}{l}\text {-Diarrhoea (in } \\
\text { neonate or older } \\
\text { calf). } \\
\text {-Respiratory } \\
\text { disorder. }\end{array}$ & Poor hygiene. & $\begin{array}{l}\text {-Watch } \\
\text { prevalence } \\
\text {-Pens are } \\
\text { cleaned prior } \\
\text { to re-housing } \\
\text { (according } \\
\text { to “Golden } \\
\text { cleaning- } \\
\text { standard.") }\end{array}$ & $\begin{array}{l}\text { Monthly } \\
\text { dairy data } \\
\text { evaluation. }\end{array}$ & $\begin{array}{l}\text { "Hygiene } \\
\text { newborn } \\
\text { calves." }\end{array}$ & $\begin{array}{l}\leq 3 \% \\
\leq 3 \%\end{array}$ \\
\hline $\begin{array}{l}\text {-Poor weight gain } \\
\text { 2- } 8 \text { weeks. }\end{array}$ & $\begin{array}{l}\text { Insufficient } \\
\text { intake milk } \\
\text { replacer/ } \\
\text { deviations in } \\
\text { composition } \\
\text { milk. }\end{array}$ & $\begin{array}{l}\text { - Water } \\
\text { temperature } \\
\text { of milk } \\
\text { preparation. } \\
\text { - Ratio milk } \\
\text { powder to } \\
\text { water. } \\
\text { - Mixing } \\
\text { time. }\end{array}$ & $\begin{array}{l}\text { Weekly } \\
\text { cleaning } \\
\text { routine. }\end{array}$ & $\begin{array}{l}\text { "Hygiene and } \\
\text { maintenance } \\
\text { of automatic } \\
\text { milk feeder." }\end{array}$ & $\begin{array}{l}370 \mathrm{~kg} \text { at } \\
14 \text { months } \\
\text { with BCS } \\
2.5 \text {. }\end{array}$ \\
\hline $\begin{array}{l}\text {-Poor weight gain } \\
2-8 \text { months. }\end{array}$ & $\begin{array}{l}\text { Insufficient } \\
\text { protein intake. }\end{array}$ & $\begin{array}{l}\text {-Concentrate } \\
\text { intake < x kg } \\
\text {-x } \% \text { of } \\
\text { animals } \\
\text { < target } \\
\text { weight. }\end{array}$ & $\begin{array}{l}\text { Young stock } \\
\text { measurements } \\
\text { 2x/year. }\end{array}$ & $\begin{array}{l}\text { "Young stock } \\
\text { measurements } \\
\text { and body } \\
\text { condition } \\
\text { scoring." }\end{array}$ & $\begin{array}{l}370 \mathrm{~kg} \text { at } \\
14 \text { months } \\
\text { with BCS } \\
2.5 \text {. }\end{array}$ \\
\hline
\end{tabular}

Table 7: Data from 12-month list of farm $\mathrm{H}$ in the $\mathrm{HH}$ and PM programme \% in months February until May were converted to prevalence figures on a yearly basis

\begin{tabular}{|c|c|c|c|c|c|c|c|}
\hline \multirow[t]{2}{*}{ Disease / Disorder } & \multicolumn{7}{|c|}{$\begin{array}{c}\mathrm{H} \\
\text { (126 dairy cows, yearly 30\% fresh heifers) }\end{array}$} \\
\hline & $\begin{array}{l}\text { \# on* } \\
07 / 02\end{array}$ & $\begin{array}{l}\text { \# on } \\
07 / 03\end{array}$ & $\begin{array}{l}\text { \# on } \\
31 / 03\end{array}$ & $\begin{array}{l}\text { \# on } \\
02 / 05\end{array}$ & $\begin{array}{l}\text { Year'05- } \\
\text { '06 }\end{array}$ & Target & $\begin{array}{l}\text { February - } \\
\text { May }(\mathrm{yb})\end{array}$ \\
\hline \# abortion & 2 & 1 & 0 & 0 & $5 \%$ & $\leq 2 \%$ & $7 \%$ \\
\hline \# abnormal births & 0 & 1 & 0 & 1 & $5 \%$ & $0 \%$ & $6 \%$ \\
\hline $\begin{array}{l}\text { \# calves dead at } \\
\text { birth }\end{array}$ & 2 & 1 & 0 & 1 & $9 \%$ & $\leq 6 \%$ & $12 \%$ \\
\hline$\#$ calves dead $>24 \mathrm{hr}$ & 1 & 0 & 0 & 0 & $7 \%$ & $\leq 5 \%$ & $3 \%$ \\
\hline \# calves: diarrhoea & 0 & 0 & 0 & 0 & $5 \%$ & $\leq 3 \%$ & $0 \%$ \\
\hline \# calves: cough & 1 & 0 & 1 & 2 & $4 \%$ & $\leq 3 \%$ & $9 \%$ \\
\hline \# barren heifers & 0 & 0 & 1 & 0 & $8 \%$ & $\leq 30 \%$ & $5 \%$ \\
\hline $\begin{array}{l}\text { \# inseminations/ } \\
\text { heifer }\end{array}$ & - & - & - & - & 1.24 & $* *$ & 1.13 \\
\hline
\end{tabular}

$*$ number of disease cases in the month prior to the farm visit. $\quad{ }^{* *}=$ not set exactly, optimally as close to 1 as possible. from these 12 -month lists, recorded during the months of the field experiment, are shown in Table 4 and Table 5.

In Figure 2 the results of the young stock measurement for farm $\mathrm{M}$ are given. The dots represent individual animals. Microsoft Excel was used to define a trend line for individual measurements; represented by the black line in Figure 2. The two dashed lines in the figure describe the on-farm tolerances $(+$ and $-5 \%$ trend line $=$ target weight tolerances for young stock growth). From the figure, the deviating animals can be spotted outside the tolerance borders. Four remarkable dots can be seen outside the $-5 \%$ tolerance border. The farmer was surprised by these findings, but when the deviating animals were identified, it became clear that each of these animals had a specific clinical history and were just marked as small animals. Approximately 10 animals were found to be 'too heavy' (above the $+5 \%$ tolerance), which confirms the presumption that some of the young stock (older than one year) had a tendency to fatten. These findings are supported by the results from the body condition scoring.

Step 10: Corrective measures In Table 6, four different work sheets for farm $\mathrm{H}$ are presented in the last column as a reference, in which are listed a 'complete' set of corrective measures for controlling an indicated hazard. Whenever a CCP or POPA was found outside its tolerance limits, the members of the HACCP team selected one corrective measure

from the developed worksheet and discussed how it could be implemented in a practical manner as part of the farm management plan. 


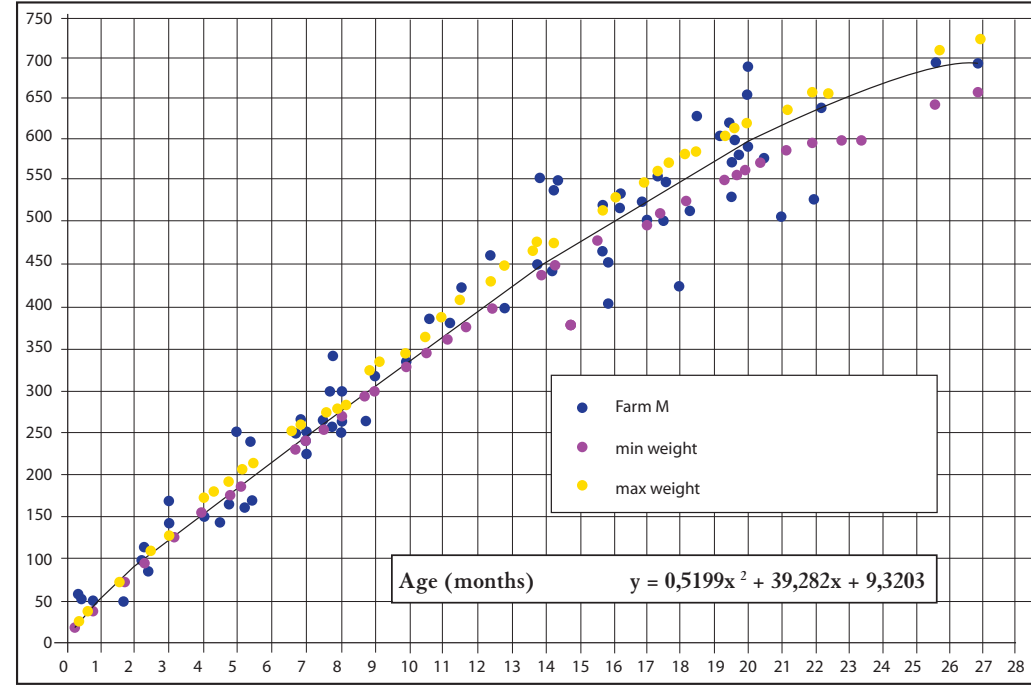

Figure 2: Growth performance of young stock on farm $M$

\section{Steps 11 and 12}

Step 11 from the HACCP concept involves establishment of record keeping procedures to document the HACCP programme is functioning. Only some of these specific record-keeping procedures were developed during this field experiment (e.g., management overview and monitoring scheme). Table 6 gives an example of HACCP record keeping, including hazards, main risks, CCPs, monitoring requirements, worksheets. (For other examples see Lievaart et al., 2005.)

\section{Discussion: HACCP programme}

To prevent top-down impractical measures in response to European food safety regulations, in this field experiment the HACCP concept was used to optimise and incorporate both young stock rearing with on-farm $\mathrm{HH}$ and PM programmes and formalisation of quality assurance in a farm situation.

The effect of the implementation of the HACCP-like programme was of more importance than understanding the formal HACCP programme itself. A farm visit should not take more than two hours for the herd sizes involved in this field experiment (Cannas et al., 2006). In order to implement the new approach within this time span, a working knowledge of the exact structure of the HACCP concept, including the 12 steps by the farmer, would have been too time-consuming and hence too costly. The manager of the HACCP team kept the overview in the implementation process; e.g., to ensure all the steps are taken, without forcing the team to follow the formal order of HACCP steps.

Originally it had also been intended to handle steps five, six, seven and eight from the HACCP steps in Table 1 during the first visit. However, the interview and survey of the management of young stock and the inspection tour on the farm took too much time (on average 2.5 hours). Therefore steps five, six, seven and eight were deferred to the next visit. Initially, the young stock management plans were set in a structured format (Table 3), before proceeding to the next steps. Having a clear management overview provided a good basis for well-considered decision-making during the next steps. The inspection tour took place after the interview, as only then a clear insight could be gained of what the farmer says and what he actually does in practice. Often unnoticed risk factors due to over-familiarity with the farm are frequently not mentioned by the farmer (because most of time, the same daily routine has been performed for years).

In step seven, the CCPs and POPAs required to eliminate or reduce the hazard in the young stock rearing process were identified, and in step eight standards and tolerances, and targets were established for triggering corrective or preventive measures associated with each CCP or POPA identified. Both concepts 'CCP and POPA' and 'standards and tolerances, and targets' need some explanation. According to the original definition, CCPs should meet five criteria, i.e., they:

1) are associated with the hazard of concern;

2) are measurable and/or observable;

3) have strict standards with tolerance limits;

4) contain corrective measures in case of deviation; and,

5) must re-establish full control of the process once lost or bring risks down to an acceptable level.

Some control points found in the dairy production process are physical in nature, for which standards and tolerances can indeed be defined (e.g., somatic cell counts). However, in young stock rearing, CCPs are more biological or managerial in nature. In that case, strict standards and tolerances have not been or cannot be defined, and hence are called POPA with a target level (Lievaart et al,. 2005). The importance of a (risk) factor contributing to certain hazards is also often not quite clear, especially the exact influence of animal welfare issues on the performance of animals, or vice versa. Criterion five frequently appears to be the bottleneck where CCPs turn out to be not absolute because in a biological process (e.g., dairy farming) corrective actions do not always result in the desired response. One physiological process may be influenced by many (risk) factors and many corrections to one factor may not be sufficient to change the whole physiological process.

Such CCPs, where absolute control is not guaranteed, are defined as POPAs instead of CCPs. From the CCP definition it can be noted that they should meet strict standards and tolerances. The establishment of strict standards and tolerances in an on-farm process is a new concept. Strict norms, which would be valid for a whole range of farms, are not realistic in a dairy process. Each farmer is a unique entrepreneur and has unique management procedures. Since on-farm management and processes vary strongly between farms, and since there is biological variation among live animals, it is more realistic to speak about farm-specific targets. Whenever targets are not reached and management results fall outside the tolerance 
limits, management or targets should be adjusted. In the on-farm HACCP programme described in this paper, the main risk factor contributing to the mismanagement was identified and eliminated. After an initial period, the effect of the corrective measures was evaluated.

There is some overlap in $\mathrm{HH}$ records for operational management (e.g., 12-month list, dairy farm wall chart, PC management information system (Brand et al., 1996)) and HACCP records. In fact, $\mathrm{HH}$ records facilitate the introduction and integration of on-farm HACCP programmes. Obviously, management evaluation can only be done when results of processes are known; therefore, recordkeeping is needed in the first place. Step 11 of the HACCP concept involves establishment of HACCP record-keeping. Only some of these specific record-keeping procedures were developed during this study (e.g., management overview, monitoring scheme and worksheets). Table 4 gives an example of HACCP record-keeping, including hazards, main risks, CCPs, monitoring requirements, worksheets. This HACCP table could be expanded with for example: 'Standards and tolerances, and targets', 'Riskestimation', 'Monitoring-frequency', 'Responsible persons' and 'Prevention', giving a more complete overview of the HACCP programme.

Verification of the programme is performed in step 12, which was not fully completed in our field experiment. Internal verification can be conducted by the evaluation of $\mathrm{HH}$ records (e.g., \% calves dead at birth, \% calves dead less than 24 hours, Table 7 and Table 4), which has been done on a regular base in the framework of $\mathrm{HH}$ and PM programme by the farmer and veterinarian for years. However, the external evaluation needed for HACCP-like certification of dairy farms, which may berequired in the future, was not performed because the duration of this field experiment was too short.

Auditors from an external (independent) institution should conduct the external verification with regard to certification (Step 12), which would include evaluation and possibly revision of the HACCP-like programme. At the start of a farm HACCP development, the external partners in the HACCP team can take the lead in a provisional, external verification; in practice this means that the farmer joins them.

The interviews ('Discussion inside' from Table 2) showed that farmers were well aware of the weakest points in their young stock management. However, farmers did not often score a three, four or five on the $\mathrm{S}$ and $\mathrm{W}$ form, indicating that farmers apparently may experience weak points but have difficulties in identifying them as real problems.

Another issue is the fact that 'opinions' are subjective. It is better to handle objective and measurable percentageintervals in each score class.

Although this field experiment focused on only one process in dairy farming (i.e., young stock rearing), it is clear that all on-farm processes together form a strongly interconnected management-complex. If one part of the management has to change, it implies that other relating farming practices have to change as well.
During the first inspection tour at farm $\mathrm{H}$, calves in the age group one to three weeks, appeared unhealthy (sluggish, watery faeces, dull hair coat). Table 7 shows that the prevalence of 'calves death greater than 24h', 'calves diarrhoea' and 'calves cough' was above the target prevalence. Since failure of passive transfer of colostrum is associated with increased prevalence of all three conditions, it was decided to monitor the antibody status of the calves. Blood was taken from four calves and checked for their serum IgG-concentrations (Table 5). Three out of four concentrations were found to be 'insufficient', nearly 'very poor', indicating that the process of colostrum feeding needed optimisation. A worksheet 'feeding newborn calves' was developed and calves were fed in accordance with this worksheet, during the rest of the field experiment. At the end of the field experiment, the colostrum feeding practice was evaluated by again checking four calves for their serum IgG levels. Compared to the first monitoring, the IgG levels had improved significantly and animals made a considerably more healthy impression. This demonstrates that a structured control programme, including the monitoring of on-farm processes and working according to protocols, improves animal health.

The calculated trend line had the same slope as the ideal onfarm growth curve (personal communication young stock nutritionist for farmers, May 2006), but the calculated trend line lies almost $100 \mathrm{~kg}$ higher at 24 months old. In order to evaluate young stock growth, the calculated trend line could be a good basis for an on-farm-ideal-growth curve. Finally, the preliminary response of the farms to the introduction of the HACCP programme on both farms was evaluated. Farmers were pleased by the clear and structured outlines of the management overview in $\mathrm{S}$ and $\mathrm{W}$ format shown in Table 3. The worksheets provided in the field experiment turned out to be practical, although the farmer must be willing to spend some extra time completing them. One farmer also stated that farmers tend to develop some kind of 'farm blindness' and that during this field experiment more attention was drawn to weaker points (e.g., hygiene and heat detection in his case). While spending more time on cubicle hygiene in the young stock barn, he had more close contact with his animals. Heat detection has improved since then and further deviations could be detected in an early stage.

Farmers found that the new approach differed from routine $\mathrm{HH}$ monitoring, since one weak or hazardous element in the on-farm management was selected and focused on in more detail. Farmers believed that the new HACCP approach could be an approach for the future. Confidence in, and adoption by the farmer of the programme is essential and it may be integrated with the on-farm $\mathrm{HH}$ programme. One of the participating farmers felt that the frequency of the visits in this field experiment (once a month) was too high. For a successful on-farm HACCP programme, the frequency of visits should be higher in the implementation phase than later. The farmer and veterinarian must be willing to invest money (e.g., monitoring serum IgG levels) and time, in order to assure a durable and solid quality assurance programme. 
Subsequently, it can be regarded as an extension to an ongoing $\mathrm{HH}$ and $\mathrm{PM}$ programme.

Furthermore, since the HACCP programme drew more attention to young stock management, farmers believed this would save money and enhancework satisfaction. One farmer believed that the HACCP team could be expanded by the inclusion of a nutritionist.

Although this field study was based on a small number of farms, it has shown that the HACCP concept may be implemented within the context of optimal calf rearing. As other studies already suggested (Noordhuizen, 2004; Cannas, 2006), the HACCP concept, offers a promising approach in order to optimise on-farm production processes, such as young stock rearing. Hazards and their associated main risk factors can be controlled within the farm specific standards and tolerances and targets by monitoring, corrective measures and implementation of farm-specific worksheets. The veterinarian, together with the farmer, plays a central role in the HACCP-team, since he/she has the knowledge to understand on-farm risk assessment and the relationship between clinical pathology, feeding and on-farm management. However, this new concept will only succeed if the farmers have good record keeping in place. Above all, farmers and veterinarians must be willing to adopt and invest extra time in a new strategy, which not only widens the scope of the veterinary profession, but also provides dairy businesses with real quality risk management programmes.

\section{Acknowledgements}

The authors would like to thank the particpating farmers and Dr Gerrit Hegen of the veterinary practice in Sleen for his support.

\section{References}

Brand, A., Noordhuizen, J.P.T.M. and Schukken, Y.H. (1996). Herd health and production management in dairy practice. First edition, pp 75-169. Wageningen: Wageningen Press.

Cannas da Silva, J., Noordhuizen, J.P.T.M., Vagneur, M., Bexiga, R., Gelfert, C. C. and Baumgartner, W. (2006). Veterinary dairy herd health management in Europe: Constraints and perspectives. Veterinary Quarterly 28 (1): 23-32.

Cullor, J. S. (1995). Implementing the HACCP programme on your clients' dairies. Veterinary Medicine 90: 290-295.

Dewell, R., Hungerford, L., Keen, J., Laegreid, W., Griffin, D., Rupp, G. and Grotelueschen, D. (2006). Association of neonatal serum immunoglobulin G1 concentration with health and performance in beef calves. Journal of the American Veterinarian Medical Association 5: 914-921. Garnsworthy, P. C. (2005). Calf and heifer rearing; Principles of rearing the modern dairy heifer from calf to calving. First edition, pp 1-9. Nottingham: Nottingham University Press.

Heeschen, W.H. and Blüthgen, A.H. (2003). Carry-over of environmenta contaminants into milk and the food hygienic assessment/management. IDF World Conference on Quality management at farm level, Brugge, Belgium.

Heinrichs, A.J., Rogers, G.W. and Cooper, J.B. (1992). Predicting body weight and wither height in Holstein heifers using body measurements. Journal of Dairy Science 75 (12): 3576-3581.

Lievaart, J.J., Noordhuizen, J.P.T.M., Van Beek, E., Van der Beek, C., Van Risp, A., Schenkel, J., Van Veersen, J. (2005). The hazard analysis critical control point's concept as applied to some chemical, physical and microbiological contaminants of milk on dairy farms. A prototype. Veterinary Quarterly 27 (1): 21-29.

Maunsell, B. and Bolton, D.J. (2004). Guidelines for Food Safety Management on Farms. pp 1-31. Ashtown: Teagasc-The National Food Centre. Mourits, M. C., Dijkhuizen, A. A., R.B.M. Huirne and D.T. Galligan. (1997). Technical and economic models to support heifer management decisions: basic concepts. Journal of Dairy Science 80 (7): 1406-1415.

Noordhuizen, J.P.T.M. (2004). Microbiological Contaminants (Zoonoses). Bulletin of the International Dairy Federation 386: 10-16.

Noordhuizen, J.P.T.M. and Metz, J.H.M. (2005). Quality control on dairy farms with emphasis on public health, food safety, animal health and welfare. Livestock production science 94 (1-2): 51-59.

Quigley III, J.D. (1996). Influence of weaning method on growth, intake, and selected blood metabolites in Jersey calves. Journal of Dairy Science 79 (12): 2255-2260.

Radostits, O.M., Gay, C.C., Blood, D.C. and Hinchcliff, K.W. (2000).

Veterinary Medicine: A textbook of the disease of cattle, sheep, pigs, goats and horses; Ninth edition, W.B. Saunders Company Ltd.

Roy, J.H.B. (1990). The calf. Fifth edition, London: Butterworth.

Ryan, D. (1997). Three HACCP-based programmes for quality management in cattle in Australia. Dairy extension NSW, Australia. Through the Dairy Discussion List. [Online] https://listserv.umd.edu/ archives/dairy-l.html Accessed December 2006. 